\title{
The Conscience of the Jury as a Basis for Delivering a Fair Verdict in Accordance with the Judicial Reform of 1864 in Russia (Historico-Juridical Research)
}

\author{
${ }^{1}$ DmitriyYu. Tumanov, ${ }^{2}$ RinatR. Sakhapov \\ 1, 2, Kazan Federal University, Naberezhnye Chelny Institute 423800, Russia, Republic of Tatarstan, City of \\ Naberezhnye Chelny, Suyumbike Pprospect, 11/29, Room 103 \\ Email:dmitriy-tumanov@mail.ru, Tel.: +79061210445, Rentsakhapov@yandex.ru, Tel.: +79274713454
}

Received: 21st October 2017 Accepted: 16th November 2017, Published: 31st December 2017

\begin{abstract}
This article proves that the basis of a fair verdict in a jury trial is the jury's conscience. The jury trial is the best guarantee of the rights and freedoms of a person suspect or accused, the best form of judicial process and trial. This court is the best guarantee of equality and justice.

The work is based on such methods as historical, systemic, formally logical, concrete-historical, comparative legal analysis method.

History knows many forms of popular participation in court. We believe that the jury trial is the most progressive and democratic form able to ensure a proper implementation and, in general, performance of all principles of judicial organization and judicial proceedings.

Our society is morally obliged to protect its institution, and, in particular, the jury trial, and the government of any state that has the great honor of introducing this institution should firmly adhere to the once adopted intention to instill an institution that has shown its great virtues for centuries in society.

We come to the conclusion that the jury is one of the central criminal justice institutions, having many centuries of practical experience. A whole range of legal principles, such as the presumption of innocence, adversariality, independence of judges, publicity, equality, justice, etc., are most fully reflected in the jury trial. And the most complete implementation of these principles is possible only within the framework of this democratic institution.
\end{abstract}

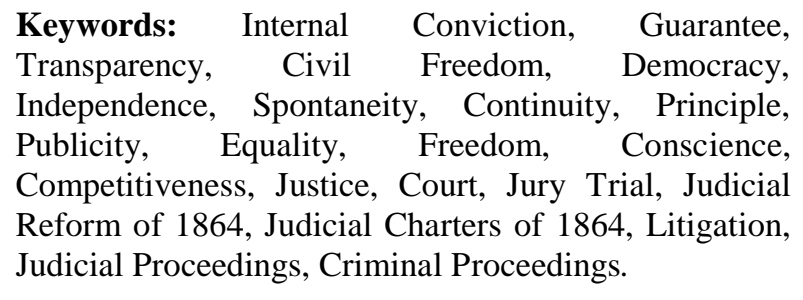

\section{Introduction}

According to many researchers, a jury trial is the best form of the court that can be specified in the history of all civilizations. The significance of this institution is enormous. Our modern society is hardly even able to understand the tremendous step to the progress it has made since it has begun to actively participate in the administration of criminal justice. It is also hardly able to understand how carefully it is necessary to cherish this precious institution, the full and normal development of which is seen by our generations. It was also quite clear to us that the period of true social activity began in the world practice since the jury bench was set up in it.

Undoubtedly, the democratic transformations in this field are possible only if there are the necessary principles on which the court and the process are based. They include competition, transparency, independence of judicial power from the legislative and executive ones, as well as the irremovability of judges, equality of parties, etc. But under all other conditions, the main thing in making a verdict by the jurors is their conscience.

Due to the study of the history of formation and development of the jury trial, due to the study of the basic principles of criminal justice, the history of formation of these principles, we can offer the world science and the science of criminal justice to improve the implementation of basic principles, namely, transparency, equality, justice, competition and many other criteria in the jury trial activity. Many aspects of the organization and activities of the modern jury trial in all countries of the world can be improved on the basis of using the historical experience of establishment of this institution in these countries. For example, the practice of organization and activities of the jury trial in the past enables to identify and classify the shortcomings of a modern jury trial, as well as a number of factors affecting the nature of the jury judgment, which provides great opportunities for further improvement of the modern legislation on jury trial. We hope that the study of foreign and domestic experience in the formation, organization and activities of the jury trial, the identification of merits and demerits, will be our contribution to the world science and the world jurisprudence.

\section{Methods}

The main methodological prerequisite of this work is the historical continuity in the development of the state and law. All the state and legal phenomena grow out of the preceding ones and are transformed into the future forms. The time connection allows us considering all phenomena in a single historical perspective. The 
development can be carried out smoothly or irregularly (evolution or revolution). A return to lost institutions, a break or a cessation of further development is possible. The analysis of the historical significance of the jury institution should reveal such conditions, causes and patterns that lead to changes in the modern jury trial. When studying the significance of jury trial, we widely used the general scientific, general philosophical, general social and concrete scientific methods.

The next method we used is the chronological method, the essence of which is that the entire study is based in a strictly defined chronological order.

A comparative legal method, which, as it is known, consists in a comparative analysis, is widely used in this work. This method is an important tool in identifying and using the positive experience accumulated at a certain stage; it helps to identify the most effective models of the state and legal regulation.

\section{Literature Review}

The issue of participation of the people's element in the criminal court attracted attention not only of the scientists, but also of the practicing lawyers of the modern and historical periods. We pay much attention in this work to the works of scientists and practicing of the XIX century, the Soviet period and the present, which include the works of the following researchers: Heinze R. [6], Gue-Gluneka [7], Danevsky V.P. [8], DeitrichV.F. [9], Koenigson A. [13], Mittermeier K. [15], PetrushevskyD.M. [20], Shaikevich S. [24], Arnold, M. S. [2], Baker, J. H. [3], Cairns, J. \&Macleod, G. [5], Daniel Klerman [14], Elliott, C. \&Quinn, F. [25], Hanly, C.[26], AgafonovS.Y. [1], Nasonov S.A.[16; 17], TarasovA.A. [22], RakhmatullinaO.R. [22].

\section{Results and Discussions}

The merit of the Russian historical experience of creating jurors was that this institution was created in the period of the developed feudal system with the low development of capitalist institutions. But it was the most important that a panel of twelve jurors united representatives of different strata of society behind a single bench, as distinct from England and other European countries.

Creation of such a democratic institution in the world as a jury trial is an important milestone in the history of the court and trial, as only a conscientious court can make fair verdicts.

The jury trial serves as a guarantee against bribery of judges and other attempts to violate their impartiality: professional judges are in the public service, and they may be subject to political (or even economic) pressure; the public is always present at the trial in the face of the same jury, ordinary citizens, and it is absolutely impossible to insist on his own for a dishonest or partial judge. The jury's decision is made by the internal conviction, but is based on conviction, which takes into account all the circumstances of the case. The chairman of the court reminds the jury about this obligation. Needless to say, it is impossible to verify whether a case has received such a decision, since the jury does not motivate their verdict, but they give the oath, they promise to give their decisive vote in accordance with what they see and hear at the trial on the real truth and conviction of conscience.

The jury is more able than the judges to be guided by justice in a true sense of the word: not having received a special training, legal education, they, having familiarized themselves with the circumstances of the case, the arguments of the parties and the parting words of the professional judge, are guided by common sense and conscience, and not formally by the dogmatic considerations.

It was widely believed that jurors, guided by conscience on the basis of internal conviction, delivered unfair sentences because they were not restricted by law, and conscience itself did not have any boundaries. But this cannot be accepted, since the laws on the jury trial give sufficient grounds for reviewing the court sentences rendered on the basis of the jury trial verdict in such cases. In addition, the jury is controlled by the society and all participants in the trial.

The jury is not bound by law, use complete freedom both in determining the reliability of fact, and in recognizing the deed as criminal. The only authority over them is their inner conviction and conscience. The jurors are guided only by the principles of justice, so if the law explained to them has been unclear or has contradicted the requirements of justice, they have repealed it in practice without giving it application. The fairness guarantees of the jury's verdicts were: initially - their unbiased position; lack of mercenary motives; a sense of moral obligation to create a court for the benefit of society, for the sake of truth, for maintaining morality in society.

In the court of lawyers, the necessity to execute the law plays an important role. A judge tethered to the law in all respects, is a device performing its letter. Thus, the principle of the court of lawyers is the law execution. Its highest virtue is the literal application of the code's decrees. The judge should motivate his decision, that is, "if the law is foolish, a known act, completely indifferent, can be considered criminal, and the judge should apply the law". If he does not do this, he will be forced to do so by the highest authority. He is tethered to the law even when determining the penalty.

The jury trial can become the greatest educational school for the people, the school of morality, civil courage and justice.

One of the undoubted merits of the jury trial is that it was due to it that the theory of formal evidence was completely withdrawn from the process. Even the ardent opponent of the jury trial V.F. Deitrich distinguished some positive aspects of this institution. They include: free and honest assessment of evidence of the defendant's guilt, having replaced the theory of formal evidence; "transparency" of the activities of investigative bodies, placed under the "glass hood", under the control of society in the person of jury, who has protected the rights of persons accused from the 
arbitrariness of investigative authorities [9, 15-16]. One of the main objections to the jury trial introduction was the inadequate development of the people. But even the members of the Government saw in this objection the grounds for the opposite conclusion, because such a people needs special protection in the court, needs judges who would fully understand it and were as close to it as possible. The argument that the jury trial is political in nature is recognized as unfounded, since it is up to the legislator to surround this institution with the conditions in which it might not have any political character.

The jury trial was the most democratic institution of judicial reform in 1864 and combined the new principles of justice: competitiveness, transparency, oralism, equality of all before the court, presumption of innocence, freedom of internal judicial conviction, protection of the defendant's right to defense and, most importantly, the jurors were guided primarily by conscience, which was mostly lacking by the Crown Court.

Undoubtedly, most of the scientists, figures of various kinds, saw the best guarantee of civil liberty in the jury trial. According to the Professor I.Ya.Foynitsky, the jury trial is "the best decoration and the strongest support of our new judicial system [23, 359].

At one time the Minister of Justice N.V. Muravyev argued about the issue of the public element in the criminal court that it was impossible to do without the assistance of citizens, inhabitants in the field of criminal justice. As the non-professional judges called from the society and the people, the jurors shared the governmental powers of the court over the criminal law violators with the judges [21, 18-19].

PetrukhinI.L. points out that one needs a great deal of everyday experience, should be unrelated to the court stereotypes, has conscientiousness and moral purity for an objective evaluation of evidence in a criminal case. A juror should have all these qualities [19].

We absolutely agree with Zakhozhy L.A. that the revival of the jury trial in Russia is "not only a procedural innovation, but can and should be considered in the context of ongoing democratic reforms". Finally, the jury trial excludes the possibility of self-incrimination, partial examinations, illegal evidence or their inadequacy.

The Senate determined the departments and the degree of power of jurors and judges in the second half of the XIX century in Russia. The mutual relations of jurors and judges, thus, in explanation of the cassation senate, were reduced to the well-known formula: de jure respondent judices, de facto juratores, - the judges decide the legal issue, and the jury - the actual one. The activities of these two factors of the court in the decision resolution should therefore appear in the following form: the jury decides on the reliability of the facts proposed by it and on the imputation of the act committed by the defendant, and the judges decide that such legitimate signs of a crime are actually carried out in the facts recognized by the jury, that the entire aggregate of these signs exhausts the required composition of a certain crime, and that the defendant should be given such a punishment $[11,61]$.

Judges and jurors, - wrote I.P. Zakrevsky, separated from each other by a stone wall, simply do not understand each other; the jurors themselves do not clearly know what they are doing, and unwillingly obey the voice of a screamer or impudent who fell into their environment; they are lost in the forest of questions, cannot make out what the court is demanding from them so persistently, and the judges cannot understand why the jury has come to this or that conclusion [10, 8-9].

N.N. Rosin noted the following in this respect: solution of the questions of fact is a task of an exclusively factual nature, it requires only "natural logic, as the authors of the Judicial Statutes have said, inherent in every person with a sound mind", as well as knowledge of life and some experience. The legal information is not necessary for solving this problem, especially since the formal pre-established evidence is anywhere used at the criminal court now. And the jurors, whose judgments are not obscured by legal wisdom, who are most interested in the fact of crime with its domestic side, and who know this domestic side closely are most suitable for making such a decision [21, 18-19].

According to M.V. Nemytina, the jury trial successfully functions in a stable society and requires high professionalism from lawyers working in its conditions. The jury verdicts may depend on random factors. The jurors have the right to recognize a person as innocent in the course of proving the crime event and the defendant's involvement in its commission [18, VIII-X].

The opponents of the jury trial spoke of this institution as a political one, both in origin and in nature [4].

So, the number of followers and supporters of the jury trial, undoubtedly, prevails over its opponents. And according to P.A. Ifland, no serious objections could be submitted against the very idea of the jury trial $[12$, 173-176].

\section{Summary}

Based on our study results, we came to the following conclusions.

Prior to the Judicial Reform of 1864, the principles of criminal justice, and, precisely the history of the formation and development of the beginnings of adversarial and investigative forms of processes are characterized by inconsistency and instability.

And only the Judicial Statutes of Alexander II adopted on November 20, 1864 in Russia radically transformed not only the judicial system and legal proceedings, but, most importantly, the attitude of society towards the court, the change in consciousness and culture of the people, the emergence of legal consciousness and legal culture, the implementation of universal and democratic principles.

In 1866 the first public trials took place in Russia, which marked the beginning of the practical implementation of the basic principles of judicial organization and judicial proceedings. One of the 
important principles and first principles proclaimed was the principle of court independence, which, in turn, allowed implementing all the other principles of criminal justice, namely, transparency, oralism, competitiveness, equality of parties, continuity, immediacy, abrogation of the formal theory of evidence assessment.

Of course, the nucleus and stronghold of the Judicial Reform of 1864 is a jury trial, which goes back many centuries, having many years of experience.

The introduction of the jury trial was a decisive step. The society was divided into two main camps: supporters and opponents of this innovation, but almost after the first processes, transparent, equal and fair, the jury trial justified itself in full.

The jury trial was established and acted under a patriarchal, class system with a form of absolute monarchy; the jury trial acted in the state in the absence of representative institutions, nevertheless, it was in the activity of the jury that all the principles of criminal proceedings, proclaimed by the Judicial Reform of 1864, were combined, and thus it was absolutely indisputable that the basic principles of the trial and process could be most fully implemented only in a jury trial, and one could not find a more correct judgment than the one proposed by A.F.Koni, who rightly pointed out that the great beginning of interpreting any doubt in favor of the defendant, theoretically recognized in our country even in our old process, found full recognition and actual implementation only on the jury trial.

Conclusions As a result of the Judicial Reform of 1864, a fast, right, merciful and just court was established, as opposed to the social and political order of Russia of that time, the central part of which was the Jury Trial - a truly popular and objective court in every sense, where each principle in the legislation could find its real expression.

\section{Acknowledgements}

The work is performed according to the Russian Government Program of Competitive Growth of Kazan Federal University

\section{References}

1. AgafonovS.Y. Evolution of Russian court of jurors in 1870-1880 as court models of public representation // Legal Science and Practice: Bulletin of the Nizhny Novgorod Academy of the Ministry of Internal Affairs of Russia. - 2014. - No. 2 (26). - P. 4044.

2. Arnold, M. S. | year=1974 $\mid$ title=Law and fact in the medieval jury trial | volume=18 | journal=American Journal of Legal History | pages $=267-180 \mid$ doi $=10.2307 / 845166$

3. Baker, J. H. | author link=John Baker (legal historian) | title=An Introduction to English Legal History | edition=4thed. | pages=72-76 location=London | publisher=Butter worths id=ISBN0-406-93053-8 | year=2002
4. BobotovS.V. Jury Trial: History and Modernity / S.V. Bobotov, N.F. Chistyakov. Moscow: Independent Publishing House "Manuscript", 1992. - 149 p.

5. Cairns, J. \&Macleod, G. (eds) | title=TheDearestBirthRightofthePeopleofEngland:TheJ uryintheHistoryoftheCommonLaw | year=2002 location=London | publisher=Hart Publishing id=ISBN1841133256

6. Heinze R. Feature of the English Judicial System in Connection with the Jury Trial / R. Heinze. St. Petersburg: Kukol-Yasnopolsky Publishing House, 1896. $-155 \mathrm{p}$.

7. Gue-Gluneka. On Jury Trial / Compositions of Gue-Gluneka; translated from the German language under the editorship of [with foreword] O. A. Filippov. - St. Petersburg: Kukol-Yasnopolsky F. House, 1865. $358 \mathrm{p}$.

8. Danevsky V.P. Comparative Review of Some Forms of the People's Court (the Court of the Sheffen, Class Representatives and Jury) / V.P. Danevsky // RusskayaMysl (Russian Thought). - 1895. - No. 1. - P. $1-21$.

9. DeitrichV.F. On Jury Trial. The Issue of its Reorganization / V.F. Deitrich. - St. Petersburg: Printing House of the Governing Senate, 1895. - 22 p.

10. ZakrevskyI.P. About the Present and Future of the Jury Trial. Collection of Articles / I.P. Zakrevsky. St. Petersburg: Printing House of P.P. Soykin, 1897. $201 \mathrm{p}$.

11. Zakhozhiy L.A., PoshivailovaA.V. Theoretical Models of the Jury Trial (in the West and in Russia): Study Guide / L.A. Zakhozhiy, A.V. Poshivailova. Vladivostok: Publishing House of the Far Eastern University, 2000. - 78 p.

12. Ifland P.A. The Day of the Fiftieth Anniversary of the Jury Trial / P.A. Ifland // Journal of the Ministry of Justice. - 1914. - No. 9. - November. P. 170-180.

13. Koenigson A. Feature of the Origin and Historical Development of the Jury Trial in the Criminal Cases / A. Koenigson. - Vitebsk: Printing House of the Provincial Government, 1871. - 109 p.

14. Daniel Klerman, "Was the Jury Every SelfInforming", Southern California Law Review 77: (2003), 123.

15. Mittermeier K. The Jury Trial and its Significance / K. Mittermayer. - Odessa: Printing House of Isakovich, 1895. - $32 \mathrm{p}$.

16. Nasonov S.A.European models of the proceedings in the trial by jury: trial by jury in Georgia (comparative legal studies) // Relevant Problems of Russian Law. - 2015. - No. 6. - P. 163-169.

17. Nasonov S.A.European models of proceedings in the trial by jury: trial by jury in Spain (comparative legal studies) // Relevant Problems of Russian Law. 2015. - No. 8. - P. 154-160.

18. NemytinaM.V. Russian Jury Trial. TeachingMethodical Manual / M.V. Nemytina. - Moscow: Publishing House of the BEK, 1995. - 218 p. 
19. PetrukhinI.L. Justice: Time of Reforms. Moscow: Nauka, 1991. - 208 p.

20. PetrushevskyD.M.The Magna Carta and the Constitutional Struggle in English Society in the Second Half of the XIII century. / D.M. Petrushevsky M.: Publishing House of M. and S. Sabashnikov, 1918. $-175 \mathrm{p}$.

21. RozinN.N. On Jury Trial. Public Lecture / N.N. Rozin. - Tomsk: Imperial Tomsk University, 1901. - 37 p. (P. 18-19)

22. TarasovA.A., RakhmetullinaO.R. Jury Trial and Problems of Popular Participation in Justice: Monograph. - M.: Publishing House "Rusains", 2015. -220 p.

23. FoynitskyI.Ya. Course of Criminal Justice / I.Ya. Foynitsky. - V. I. - St. Petersburg: Publishing House "Alfa", 1996. - 594 p.

24. Shaikevich S. On the Jury Trial. Composition of Gue-Gluneka, translated from German language under the editorship of O.A. Filippov / S. Shaikevich. St. Petersburg: University Publishing House (Katkov and Co.), 1865. - 360 p.

25. Elliott, C. \&Quinn, F. | title=English Legal System | pages=Ch.5 | ed=2nded. | year=1998 | id=ISBN1405847336 | location=London publisher=Longman $\mid$ edition=8thed.

26. Hanly, C. (2005). "The decline of civil jury trial in nineteenth-century England". Journal of Legal $\begin{array}{llll}\text { History } & 26 & \text { (3): } & \text { 253-278. }\end{array}$ doi:10.1080/01440360500347525 